University of Nebraska - Lincoln

DigitalCommons@University of Nebraska - Lincoln

1988

\title{
A Statistical Evaluation of Formation Disturbance Produced by Well-Casing Installation Methods
}

Roger H. Morin

Denver Federal Center, roger.morin49@gmail.com

Denis R. LeBlanc

Denver Federal Center

Warren E. Teasdalea

Denver Federal Center

Follow this and additional works at: https://digitalcommons.unl.edu/usgsstaffpub

Part of the Earth Sciences Commons

Morin, Roger H.; LeBlanc, Denis R.; and Teasdalea, Warren E., "A Statistical Evaluation of Formation Disturbance Produced by Well-Casing Installation Methods" (1988). USGS Staff -- Published Research. 348.

https://digitalcommons.unl.edu/usgsstaffpub/348

This Article is brought to you for free and open access by the US Geological Survey at DigitalCommons@University of Nebraska - Lincoln. It has been accepted for inclusion in USGS Staff -- Published Research by an authorized administrator of DigitalCommons@University of Nebraska - Lincoln. 


\title{
A Statistical Evaluation of Formation Disturbance Produced by Well-Casing Installation Methods
}

\author{
by Roger H. Morin, Denis R. LeBlanc, and Warren $E_{\text {" Teasdale }}{ }^{a}$
}

\begin{abstract}
Water-resources investigations concerned with contaminant transport through aquifers comprised of very loose, unconsolidated sediments have shown that small-scale variations in aquifer characteristics can significantly affect solute transport and dispersion. Various sampling and borehole-logging techniques have been integrated into these studies to detect and measure detailed formation changes through casing or well screen along the length of the borehole. Commonly, measurement accuracy and resolution have been limited by a borehole environment consisting of an annulus of disturbed sediments produced by the casinginstallation method.

In an attempt to quantify this disturbance and recognize its impact on the characterization of unconsolidated deposits, three installation methods were examined and compared in a sand-and-gravel outwash at a test site on Cape Cod, Massachusetts. These installation methods were: (1) casing installed in a mud-rotary hole; (2) casing installed in an augered hole; and (3) flush-joint steel casing hammerdriven from land surface. Fifteen wells were logged with epithermal neutron and natural gamma tools. Statistical analyses of these digitized nuclear logs proceeded under the fundamental hypothesis that a large variance indicated preservation of layering in the surrounding sediments, significant variability at a small scale, and a small level of disturbance. Conversely, a small variance corresponded to mixing, poor detail, and larger disturbance. The statistical information generated from a systematic "analysis of variance" investigation confirmed an intuitive assessment of the problem by demonstrating that, under the conditions encountered at this site, augering is the most disruptive of the three casing-installation methods and that driving casing directly, though typically a more time-consuming operation, transmits the least amount of disturbance into the surrounding formation.
\end{abstract}

\footnotetext{
${ }^{a}$ U.S. Geological Survey, Denver Federal Center, Box 25046, M.S. 403, Denver, Colorado 80225 .

Received June 1987, revised September 1987 , accepted October 1987.

Discussion open until September 1, 1988.
}

\section{INTRODUCTION}

Recent reports concerned with onsite and theoretical studies of contaminant transport in aquifers comprised of unconsolidated sediments have shown that small-scale spatial variations in physical properties can significantly affect solute movement and dispersion (Molz and others, 1986; Mackay and others, 1986; Sudicky and others, 1983). For example, the heterogeneity of hydraulic conductivity is believed to cause macro-scale dispersion of solutes observed in field-scale contaminant plumes (Gelhar and Axness, 1983; Anderson, 1979). Fine-scale distribution of aquifer properties generally has been ignored in groundwater investigations because these studies typically are designed to evaluate large-scale hydrogeologic phenomena. Nevertheless, research on the detection and measurement of these variations has expanded as the recognition of their importance in controlling contaminant transport has grown (Sudicky, 1986). For instance, many sand-and-gravel aquifers are thin (less than 100 feet thick) and highly permeable, and contrasts in physical properties may range from subtle to substantial over relatively short vertical distances (1-2 feet).

The U.S. Geological Survey is conducting a multidisciplinary research program concerning the transport and fate of contaminants in ground water at a test site on Cape Cod, Massachusetts. One aspect of this effort is the use of high-resolution borehole geophysical logs capable of detecting small-scale vertical variations in formation characteristics. Correlation of these logs with physical properties measured on recovered core and in test wells provides a useful basis for analyzing the distribution of formation characteristics and for evaluating aquifer heterogeneity. Because the test site consists of a sand-and-gravel outwash, the wells 
that penetrate these loose, unconsolidated deposits must be cased immediately to prevent collapsing and to permit access with logging tools.

It became apparent in the early stages of this program that the mandatory installation of casing was producing an annulus of disturbed sediments in the vicinity of the borehole. Detailed stratification in the outwash was being compromised and this situation, in turn, was seriously limiting the accuracy and resolution of the geophysical logs. This fundamental problem had to be resolved satisfactorily before suitable correlation and interpretation among logs, core measurements, and well tests could proceed. It is in this context, therefore, that the following study was initiated. This report presents the results of preliminary logging activity at the Cape Cod site and proposes a statistical approach for evaluating the degree of formation disturbance produced by different casing-installation methods.

\section{SITE DESCRIPTION}

The test site is located on an extensive glacial outwash plain that forms the western part of Cape Cod, Massachusetts (Figure 1). The outwash plain was deposited by braided streams that emanated from the receding ice sheets at the end of the Pleistocene Epoch about 10,000 years ago (Oldale, 1981 ; Mather and others, 1942). The plain slopes southward from the moraines that form the backbone of Cape Cod to Nantucket Sound.

The test holes in this study are in an abandoned gravel pit (Figure 1) located midway between the moraines and the ocean. The gravel pit also is the site of a large natural-gradient tracer test being conducted to measure dispersion in the aquifer. Disposal of treated sewage since 1936 through nearby infiltration beds at Otis Air Base has formed an extensive plume of contaminated ground water which underlies the test site (LeBlanc, $1984 \mathrm{a} ; 1984 \mathrm{~b})$. This plume is estimated (1986) to be 3,000 feet wide, 75 feet thick, and more than 11,000 feet long.

In this region, the sand and gravel is over 100 feet thick and is underlain by finer-grained silty sand and till (Figure 2). The sand and gravel occurs in horizontal lenses and layers, 1 to 2 feet thick in shallow test pits. Sediment grains are mostly igneous and metamorphic rock fragments, predominantly quartz and feldspars; the mean grain size of core samples retrieved from the region is 0.59 millimeters (LeBlanc, 1984c). The outwash generally becomes finer with depth, although silt and clay comprise less than 5 percent of the

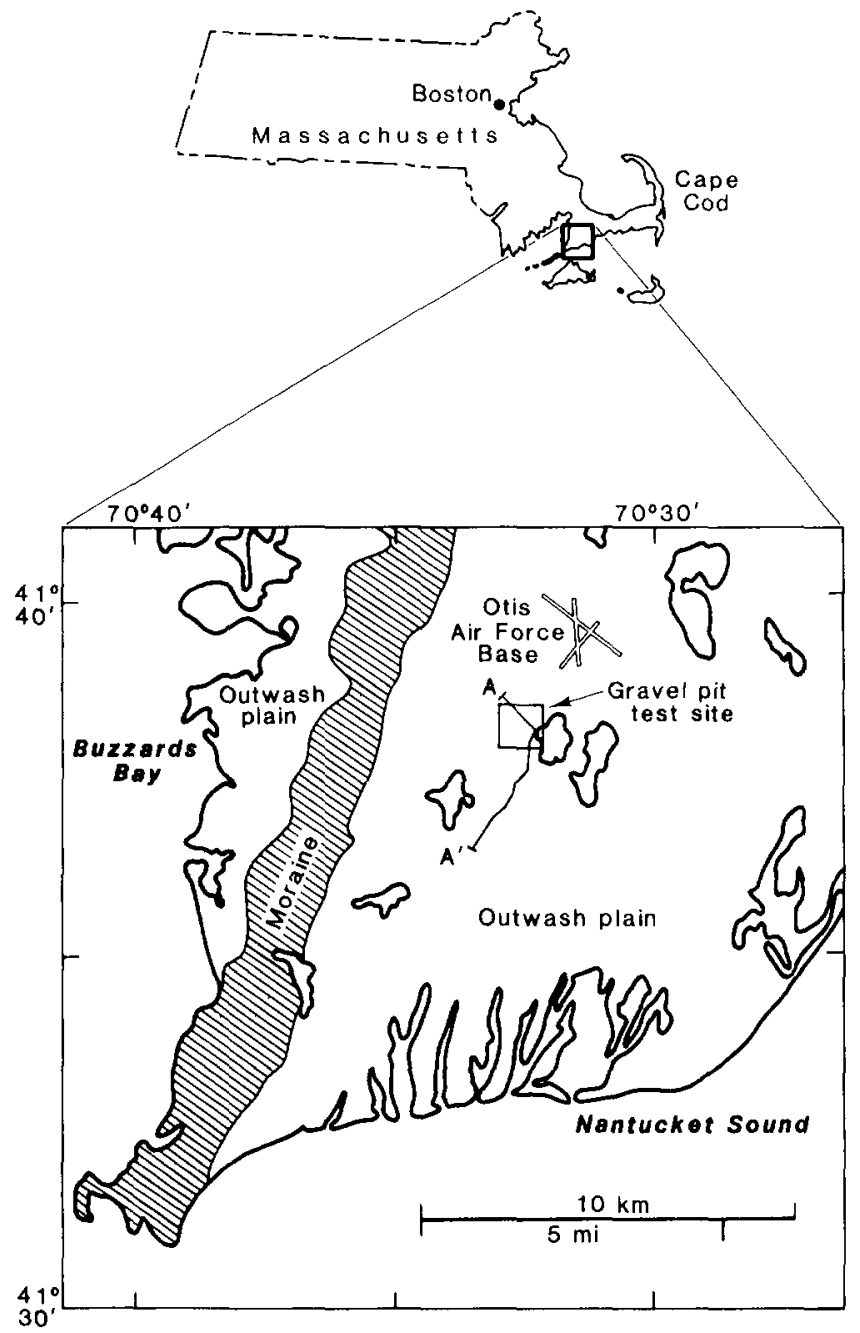

Fig. 1. Study area. Cross section of line $A-A^{\prime}$ is shown in Figure 2.

deposits. Average hydraulic conductivity of this glacial material is about 380 feet per day, with an effective porosity estimated to be about 0.38 ; regional ground water is unconfined and moves southward toward Nantucket Sound at a rate of about 1.6 feet per day (LeBlanc and others, 1987).

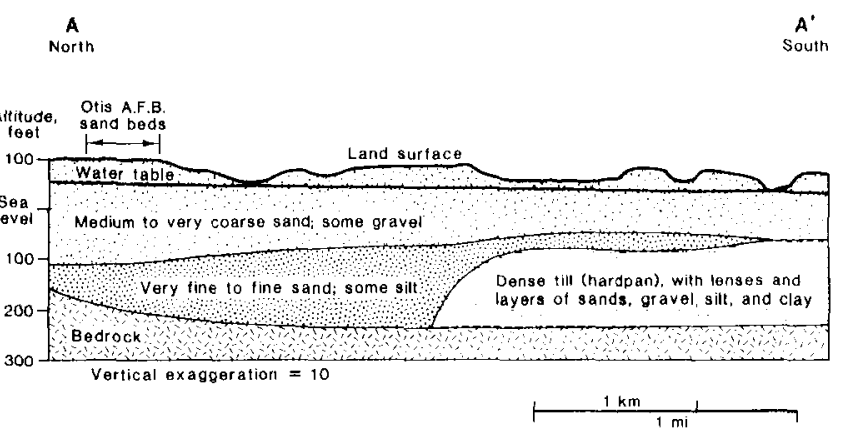

Fig. 2. Geologic section showing hydrogeologic units in the study area. Location of section line $A \cdot A^{\prime}$ is shown in Figure 1. 


\section{CASING-INSTALLATION METHODS}

Three methods of setting well casing were used to install a network of 15 wells interspersed across the study site (Figure 3 ). Eight wells were constructed by augering, traversing the site along intersecting east-west and north-south patterns; three wells were constructed by mud-rotary drilling; four wells were constructed by hammer-driving steel casing. The driven wells are separated into two pairs located at opposite ends (north-south) of the gravel pit.

\section{Hollow-Stem Augered Method}

To avoid any problems with hole caving or collapsing due to the loose, unconsolidated nature of the aquifer, hollow-stem augers were used to drill boreholes and install well casings in a single operation. The augers were key coupled, 5 feet long, with a $6 \frac{5}{8}$-inch outside diameter (O.D.) and a 31/4-inch inside diameter (I.D.). An expendable knockout disc was located at the bottom of the auger in lieu of a conventional center-rod assembly; this disc prevented sediments from entering the hollow stem during drilling. The disc was seated in a milled-out part of the auger head (finger-type bit) and secured in place by means of a wire snap-ring.
After the hole had been advanced to the desired depth, the auger was pulled back about 6 inches off the bottom; the casing was inserted through the auger stem; the expendable disc was knocked out. Then the auger was removed and the sediments were allowed to collapse against the smaller, flushjoint steel casing (size NXWL; $27 / 16$-inch I.D. by $2^{13 / 16}$-inch O.D.).

\section{Mud-Rotary Drilled Method}

Three holes were produced by a conventional mud-rotary drilling method using a $3 \% / 8$-inch tricone rolling-cutter bit. Shuter and Teasdale (in press) have presented a detailed description of this technique. The drilling mud was a high-yield, premiumgrade, western sodium bentonite. It was mixed in a 400-gallon capacity portable tank to a Marsh-funnel viscosity of 36 to 38 seconds and a mud density of 8 to 9 pounds/gallon. The $\mathrm{pH}$ of the mud, measured by a paper indicator strip, was approximately 8 .

Drilling was begun after the mud had been mixed thoroughly in the portable tank. The drillingfluid mixture was circulated at a rate of about 50 gallons/minute during the drilling operation. This circulation rate was sufficient to adequately remove the drilled cuttings (including some gravels) from

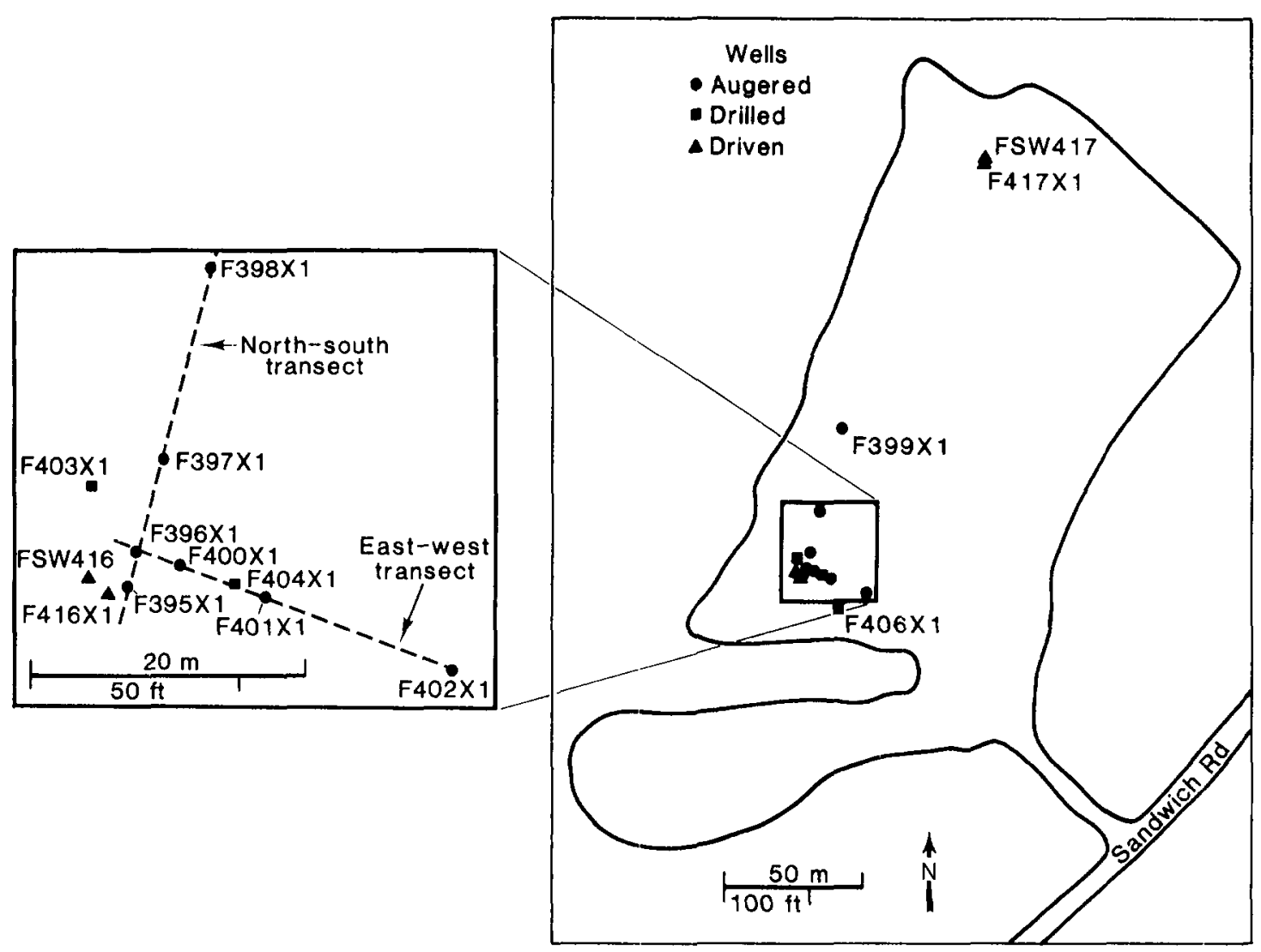

Fig. 3. Plan view of test site showing location of wells. 
the hole, cool the bit, lubricate the drill tools, and form a thin filter cake (rind) on the borehole wall that minimized fluid losses into the formation. Upon completion of the drilling, the hole was conditioned for casing installation by lifting the drill rods off the bottom of the hole (about 6 to 12 inches) and circulating the drilling fluid for a sufficient period of time to remove the suspended cuttings. Fluid circulation was continued at a moderate rate, so as not to erode the borehole, until the return flow essentially was free of cuttings.

After the hole had been stabilized and thoroughly flushed, the drill rods were pulled out using a vented hoisting swivel. This was done to avoid imparting vacuum on the wall of the borehole that would have caused a swabbing effect resulting in localized caving and ultimate hole collapse. After the rods were removed, the casing was installed and the remaining drilling fluid was flushed out. Well F $404 \mathrm{X} 1$ constains the same steel casing used in the augered holes; wells F403X1 and F406X1 contain schedule 40, flush-joint, PVC pipe ( $2 \frac{1}{16}$-inch I.D. by $2 \frac{3}{8}$-inch O.D.).

\section{Hammer-Driven Method}

Four casings were installed by a hammer-driven method in two sets of pairs, 600 feet apart (Figure $3)$. In this method, an open-ended steel casing was driven the full depth of the desired logging interval with a 300-pound drive hammer. The drive casing (size NXWL) was the same flush-jointed steel pipe used with the hollow-stem augers. Sediment that entered the casing during the driving operation subsequently was washed out with water. Casings for wells $\mathrm{F} 416 \mathrm{X} 1$ and $\mathrm{F} 417 \mathrm{X} 1$ were installed in this manner.

A variation of this method was employed with wells FSW416 and FSW417. First, a pilot hole was drilled to the water table (15 to 19 feet below land surface) with a series of hollow-stem augers. Then, an open-ended, flush-jointed, size NW steel casing ( 3 -inch I.D. by $3 \frac{1}{2}$-inch O.D.) was inserted into the augers (that now served as a support guide) and was driven to the full depth of the well. Sediment that entered the casing during driving again was washed out. Schedule 40 PVC casing with slotted screen was lowered inside the steel pipe to the bottom of the hole, and the drive casing and the supporting augers were then retrieved. The thickness of annulus between the O.D. of the PVC casing and the O.D. of the steel pipe was only $9 / 16$ inch, so formation disturbance caused by collapse of sediments against the PVC after removal of the outer drive casing was not expected to be significant. This assumption is supported by the geophysical logs and related statistical data, some of which are presented hereafter. This casinginstallation method produces a hybrid hole, augered above the water table and driven below it. Because only the portion below the water table is examined in this study, these wells are classified as being driven.

\section{GEOPHYSICAL LOGS}

The presence of metal or plastic casing in all wells precluded the use of electric or acoustic measurements as part of the logging program; logging activity was relegated to temperature and nuclear logs. Of these, attention concerning this formation-disturbance study primarily was focused on the epithermal neutron and the natural gamma logs.

The neutron tool consists of a neutronemitting source and a detector. The probe response is mostly due to hydrogen in the vicinity of the borehole and, therefore, to water as well. Unlike gamma rays, neutrons interact almost exclusively with atomic nuclei. The epithermal neutron tool used in this study contained one source and one detector spaced 10 inches apart, and logs were produced by counting the number of neutrons backscattered and slowed by the surrounding formation within a specific energy level; an epithermal tool detects particles with energies between 0.1 and 1000 electron volts (Hearst and Nelson, 1985). Logs were digitized at 0.5-foot intervals in units of counts per second (cps). The tool has a diameter of $1 \frac{1}{2}$ inches and was run without centralizers at a logging speed of 20 feet/ minute. Since each digitized value of counts was collected over a one-second time span, this logging speed translates into one value of count rate integrated over each 4-inch depth interval. Typical neutron logs for three wells which correspond to the three different methods of casing installation are presented in Figure 4.

The natural gamma tool provides a measure of the natural gamma radiation being emitted by all deposits in the aquifer. Most of this activity is generated by potassium- 40 and daughter products in the uranium and thorium decay series. The gamma probe does not distinguish among the various radioactive elements; it does, however, provide a useful diagnostic signature of the formation under study. Clays tend to accumulate radioisotopes through adsorption and ion-exchange processes, and the gamma activity of clay-bearing 


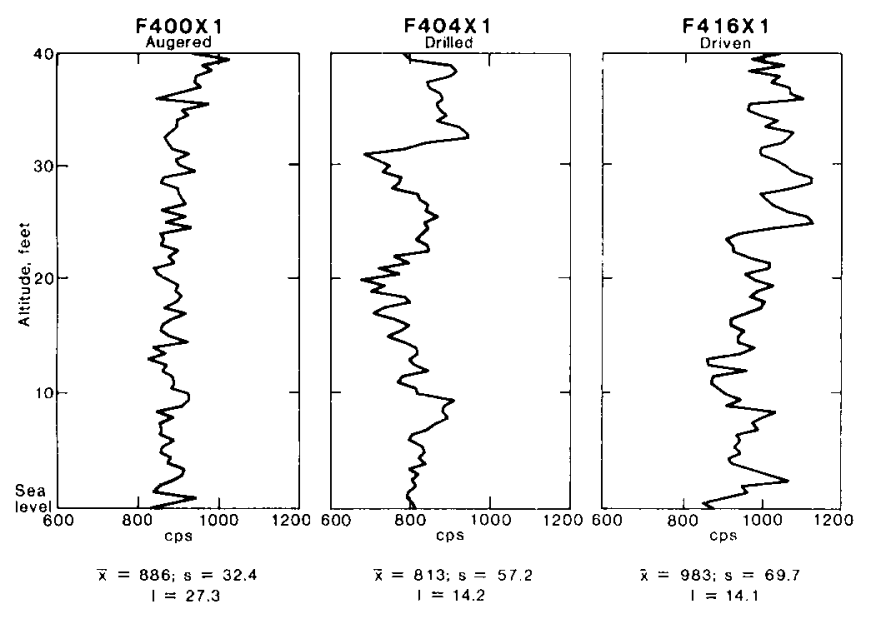

Fig. 4. Neutron logs obtained from wells representative of the three casing-installation methods. Well locations are shown in Figure $3 ; \bar{x}, s$, and $I$ are defined in the text.

sediments regularly is larger than that of siliceous and calcareous deposits (Keys and MacCary, 1971). Representative natural gamma logs, again corresponding to the three casing-installation methods, are presented in Figure 5.

The natural gamma tool used to log wells $\mathrm{F} 400 \mathrm{X} 1$ and $\mathrm{F} 404 \mathrm{X} 1$ (Figure 5 ) was $1 \frac{7}{8}$ inches in diameter, with a $1 \times 3$-inch detector crystal. This probe began to malfunction midway through the logging program, and it subsequently was

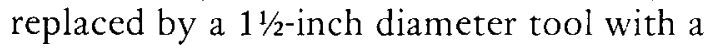
$3 / 4 \times 1$-inch detector crystal. This smaller crystal accounted for lower absolute count rates evident in a few wells, as is exemplified with the log obtained from well F416X1 (Figure 5). Both gamma tools were free-hanging and run without centralizers. As with the neutron logs, natural gamma logs also were digitized at 0.5 -foot intervals while maintaining a logging speed of $20 \mathrm{feet} / \mathrm{minute}$.
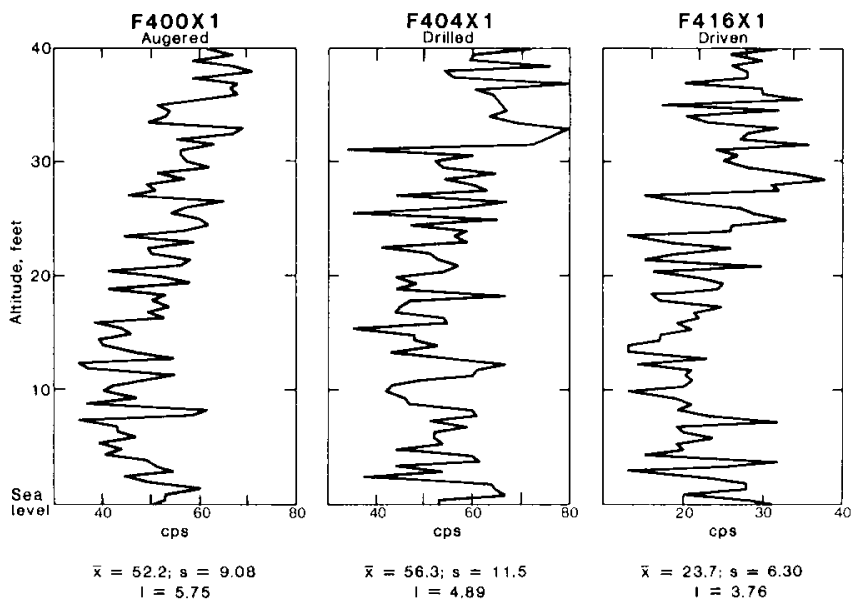

Fig. 5. Natural gamma logs obtained from wells representative of the three casing-installation methods. Well locations are shown in Figure $3 ; \bar{x}, s$, and $I$ are defined in the text.

\section{EXPERIMENTAL DESIGN AND STATISTICAL ANALYSES}

Digitized neutron and natural gamma logs of the 15 wells in this study provide a comprehensive data base from which to develop an experimental design and proceed with various statistical exercises. Comparisons of logs from different wells are made across a common 38 -foot depth interval below the water table. The 0.5 -foot digitizing interval provides a total of 77 values of count rate $(n=77)$, as determined by either the neutron or the natural gamma detector, for each well. The following "analysis of variance" approach evaluates these data sets in terms of location within the study site and casing-installation method. The statistical formulation of this analysis using neutron logs is summarized in Table 1 .

Standard progression for performing a parametric "analysis of variance" requires (1) a prerequisite test for normality, followed by (2) a chi-square test for equality of variances, and (3) an F-test for equality of population means (Conover, 1980). Failure of any test invalidates the succeeding one. For all 15 data sets derived from the neutron logs, the assumption of normal distribution proved to be valid as determined from the graphical technique developed by Lilliefors (1967). The following statistical analyses proceed under the fundamental assumption that a large variance indicates preservation of layering in the surrounding sediments, significant variability at a small scale, and a small level of disturbance. Conversely, a small variance corresponds to mixing, poor detail, and larger disturbance.

\section{Identifying Variables}

Before a valid comparison can be made of the various well logs classified solely in terms of casinginstallation method, the variability among logs from wells installed by the same method must be examined for extraneous variation. Does evidence of spatial heterogeneity occur at the study site and, if so, how does this additional variable affect the evaluation of formation disturbance? Thus, a prerequisite analysis is necessary to determine whether or not wells constructed by the same casinginstallation method yield statistically indistinguishable logs, regardless of location within the study site.

Test 1: This initial analysis consisted of examining neutron logs from the eight augered wells. These specific logs were chosen because: (1) the larger number of augered wells, eight, as compared to four driven and three drilled wells, 
Table 1. Synopsis of Statistical Tests Derived from Neutron Logs

\begin{tabular}{|c|c|c|c|c|c|c|c|c|c|c|c|}
\hline \multirow[b]{2}{*}{ Test } & \multirow[b]{2}{*}{ Null hypothesis } & \multirow{2}{*}{\multicolumn{2}{|c|}{$\begin{array}{l}\text { Installation }{ }^{*} \\
\text { method a }\end{array}$}} & \multirow[b]{2}{*}{$n$} & \multicolumn{3}{|c|}{$\begin{array}{l}\text { Chi-square test for } \\
\text { equal variance }\end{array}$} & \multicolumn{3}{|c|}{$\begin{array}{l}\text { F-test for } \\
\text { equal mean }\end{array}$} & \multirow[b]{2}{*}{ Conclusion } \\
\hline & & & & & $\chi^{2}$ & $P$ & $\begin{array}{l}\text { Result at } \\
\alpha=0.050\end{array}$ & $F$ & $P$ & $\begin{array}{l}\text { Result at } \\
\alpha=0.050\end{array}$ & \\
\hline 1 & $\begin{array}{l}\text { Population variances of } \\
\text { neutron logs from all } \\
\text { augered wells are equal }\end{array}$ & A & 8 & 77 & 25.4 & $<0.005$ & reject & - & - & - & $\begin{array}{l}\text { Evidence of spatial } \\
\text { heterogeneity across site }\end{array}$ \\
\hline 2 & $\begin{array}{l}\text { Population variances and } \\
\text { means from adjacent } \\
\text { augered wells are equal }\end{array}$ & A & 3 & 77 & 4.67 & $>0.050$ & accept & 1.10 & $>0.250$ & accept & $\begin{array}{l}\text { Spatial heterogeneity } \\
\text { is scale dependent }\end{array}$ \\
\hline ba & $\begin{array}{l}\text { Population variances and means } \\
\text { from augered wells along } \\
\text { E-W transect are equal } \\
\text { Population variances from } \\
\text { augered wells along } \\
\text { N-S transect are equal }\end{array}$ & A & 3 & 77 & 5.54 & $\begin{array}{l}>0.100 \\
>0.025\end{array}$ & accept & - & - & - & $\begin{array}{l}\text { Spatial heterogeneity } \\
\text { is dominated by } \\
N-S \text { variability }\end{array}$ \\
\hline 4 & $\begin{array}{l}\text { Population variances from } \\
\text { three adjacent wells installed by } \\
\text { different methods are equal }\end{array}$ & $\begin{array}{l}A \\
M \\
D\end{array}$ & 3 & 77 & 40.0 & $<0.005$ & reject & - & - & - & $\begin{array}{l}\text { Variability of variances is a } \\
\text { function of casing-installation } \\
\text { method and location }\end{array}$ \\
\hline 5 & $\begin{array}{l}\text { Population variances and means } \\
\text { of I values from augered holes } \\
\text { along E-W and } N-S \text { transects } \\
\text { are equal }\end{array}$ & A & 2 & 4 & 4.79 & $>0.100$ & accept & 4.58 & $>0.250$ & accept & $\begin{array}{l}\text { Disturbance index eliminates } \\
\text { dependence of statistical } \\
\text { parameters on location } \\
\text { across site }\end{array}$ \\
\hline 6 & $\begin{array}{l}\text { Population variances and means } \\
\text { from adjacent wells with } \\
\text { different casings are equal }\end{array}$ & $D$ & 2 & 77 & 1.23 & $>0.250$ & accept & 2.21 & $>0.250$ & accept & $\begin{array}{l}\text { Statistical effects of casing } \\
\text { size and material are not } \\
\text { significant }\end{array}$ \\
\hline 7 & $\begin{array}{l}\text { Population variances and means } \\
\text { of I values from all wells } \\
\text { are equal }\end{array}$ & $\begin{array}{l}A \\
M \\
D\end{array}$ & 3 & $\begin{array}{l}8 \\
3 \\
4\end{array}$ & 1.30 & $>0.500$ & accept & 18.7 & $<0.005$ & reject & $\begin{array}{l}\text { Values of } 1 \text { from all } \\
\text { wells have similar } \\
\text { variances; differences } \\
\text { in means are significant } \\
\text { and are dependent } \\
\text { upon casing-installation } \\
\text { method }\end{array}$ \\
\hline
\end{tabular}

*A auger, $M$ - mud-rotary drill, $D=$ drive

provided a broader statistical base; (2) the augered wells encompassed a larger portion of the study site; (3) all augered wells contained the same type of casing $\left(2 \frac{7}{16}\right.$-inch I.D. steel), thereby avoiding any uncertainties introduced into the analysis by casings of different size and material; and

(4) the same neutron tool was used throughout the logging program; i.e., all wells were logged with a common tool. This last criterion was not met with the natural gamma probe because it was replaced midway through the study. Therefore, Test 1 was designed such that logging tool and casing were common to all data sets.

A chi-square test can be used to decide upon the validity of the null hypothesis that states that variances from all augered holes are statistically equal (Snedecor and Cochran, 1967). Because the resulting estimate of probability $(\mathrm{P})$ is below the level of significance chosen for this analysis $(\alpha=0.05)$, the supposition of equal variance must be rejected (Table 1 , Test 1 ). This result indicates that variance may be a function of well location. It follows that a corresponding F-test for this first case theoretically is not valid.

Test 2: The next logical step is to repeat the previous test on a smaller scale, considering only a few augered wells which are very close to each other. Wells F395X1, F396X1, and F400X1 qualify (Figure 3), and their neutron logs are evaluated. If only closely spaced wells are analyzed, the null hypothesis of equal variance is not rejected (Table 1, Test 2); the corresponding F-test with the 
null hypothesis of equal population means is strongly accepted $(\mathrm{P}>0.250)$.

Thus, the results of Tests 1 and 2 appear to indicate spatial heterogeneity at the Cape Cod site. When only adjacent wells are considered, strong similarities among variances and among means are evident. However, as the area of investigation is expanded to include a larger portion of the gravel pit, this agreement deteriorates.

Test 3: Spatial heterogeneity can be examined further to determine if any obvious patterns in its distribution (anisotropy) can be identified. The plan view of the well locations shown in Figure 3 illustrates that the augered holes are oriented along intersecting east-west and north-south directions. The neutron logs from the four wells that define the east-west transect (wells F396X1, F400X1, $\mathrm{F} 401 \mathrm{X} 1$, and $\mathrm{F} 402 \mathrm{X} 1$ ) are determined to have equal variance and unequal means (Table 1 , Test $3 \mathrm{a}$ ). However, the hypothesis of equal variance is rejected (Table 1 , Test $3 \mathrm{~b}$ ) for those wells that form the north-south transect (wells F395X1, F397X1, and F398X1). Well F399X1 was excluded from this analysis so that the lengths of the two transects and, therefore, the pertinent ranges of investigation would be approximately the same. Because equal variance is observed only along the east-west transect, it appears that the spatial heterogeneity identified in Test 1 is preferentially oriented in the north-south direction. Although north-south is also considered to be the primary direction of deposition in this region, further detailed examination of geologic evidence supporting this conjecture is beyond the scope of the present study.

Test 4: Neutron logs from three adjacent wells (F400X1, F404X1, and F416X1) that were constructed with the same type of casing material, but installed by three different methods, can be tested for equal variance to investigate the effects of installation on formation preservation. With this exercise, uncertainties associated with changing well location and casing type are avoided and the principal variable, casing-installation method, is isolated. The three neutron logs utilized in this test are shown in Figure 4. The test for equal variance fails at the established level of acceptance (Table 1 , Test 4), suggesting that the variances of the neutron logs exhibit a strong dependency on the casing-installation method. Thus, the systematic series of statistical exercises listed above (Tests 1 through 4) have established that the population variances of the neutron logs are functions of: (1) location within the study site, where spatial heterogeneity appears to be dominated by northsouth variability; and (2) casing-installation method.

\section{Quantifying Relative Disturbance}

Tests 1 to 4 were designed to focus on the inherent factors that affect $\log$ response at this particular test site. Their results provide the basis for analytically evaluating formation disturbance. The coefficient of variation $(\mathrm{CV})$ is the ratio of the standard deviation to the mean. In this application, its inverse can be perceived as a relative measure of disturbance, a type of disturbance index (I) defined as follows:

$$
\mathrm{I}=1 / \mathrm{CV}=\overline{\mathrm{x}} / \mathrm{s}
$$

where $\mathrm{I}=$ disturbance index (dimensionless); $\mathrm{CV}=$ coefficient of variation (dimensionless); $\overline{\mathrm{x}}=$ mean (cps); and $\mathrm{s}=$ standard deviation (cps). Mixing of fine strata near the borehole should not affect significantly the absolute value of the mean of the nuclear log. However, this homogenization process should result in a "smearing" of the log signature, causing the standard deviation to decrease and the magnitude of I to proportionally increase.

Test 5: The population variances and means analyzed earlier were found to be functions of both location and casing method. The next few statistical exercises are designed to determine if the disturbance index exhibits the same degree of dependency upon these two factors. A test for equal variance is performed on eight values of $I$, one calculated for each of the augered holes. These values are classified spatially into two categories $(\mathrm{a}=2)$ : east-west wells $(\mathrm{n}=4)$ and north-south wells $(n=4)$. The prerequisite test for normality is satisfied and the null hypothesis of equal variance holds (Table 1, Test 5), indicating that there is little difference between the variance of I values for east-west wells and for north-south wells. Because $a=2$, this test of equality of variance is technically not a chi-square test.

An F-test with the null hypothesis stating that the values of I for augered wells (east-west compared to north-south) have the same population means, regardless of transect direction across the study site, also is accepted. Thus, by introducing the disturbance index into the experimental design, the variations in population variances and means due strictly to spatial heterogeneity have been normalized to a common reference.

Test 6: The definitive analysis of this report (Test 7) attempts to quantify disturbance as a 
function solely of the casing-installation method. It incorporates data from all 15 wells and, as such, considers some wells which contain different types of casing. Before proceeding with that final exercise, one other analysis must be included to examine the degree of extraneous variation caused by casing type. Wells F417X1 and FSW417 are evaluated. These were produced by the same casing. installation technique (driven) and are adjacent to each other (Figure 2). However. well F417X1 has a $27 / 16^{7}$-inch I.D. steel casing, whereas well FSW417 has a $2 \frac{1}{16}$-inch I.D. PVC casing. Results of statistical tests conducted between the neutron logs obtained from these two holes imply that both wells have the same population variances and means, irrespective of casing type (Table 1, Test 6). As expected, the computed values of I are similar $\left(\mathrm{I}_{\mathrm{r} 417 \mathrm{X} 1}=17.9, \mathrm{I}_{\mathrm{FSW} 417}=17.2\right)$. An analysis equivalent to Test 6 , conducted on the other pair of driven wells (F416X1 and FSW416), yields the same observation. Accordingly, the conclusion can be drawn that changes in casing size and material, within the ranges encountered in this study, apparently have no discernible impact on the statistical results. Statistical comparisons of disturbance index now can be made among all wells classified in terms of a single variable, casinginstallation method. Results should be sensitive to the purposes of this study.

Test 7: Results of the six tests described above provide the statistical background and justification from which to compare the formation disturbances produced by the three methods of casing installation. All 15 wells are classified according to a sole criterion, casing-installation method, and associated values of disturbance index computed from the neutron logs are tested for equal variance (Table 1 , Test 7$)$. The large probability $(P>0.500)$ resulting from the chi-square test demonstrates the near equality of variances for the three installation methods. However, the succeeding hypothesis of equality of means is strongly rejected $(\mathrm{P}<0.005)$. Thus, although the variances of I are similar for all wells, distinct differences exist in the means of the disturbance indices which appear to be related to casing method. The mean values of the disturbance indices ( $\bar{I}$ ) for each method, as determined from the neutron logs, are listed in Table 2 and are depicted pictorially in Figure 6 as (a) empirical distribution functions (e.d.f.'s), and (b) bar graphs. The magnitude of $\bar{I}$ is a quantitative estimate of the relative formation disturbance produced by a casing-installation method. Although the null hypothesis of Test 7 stating equal means is rejected, it lends no additional information on the relative ordering of the different population means. Computing the standard error (s.e.) is a technique used for multiple comparisons that determines the difference in the mean values of I between two installation methods $\left(\overline{\mathrm{I}}_{\mathrm{A}}-\overline{\mathrm{I}}_{\mathrm{B}}\right)$. It is calculated as follows, using variances and numbers of wells as listed in Table 2.

$$
\begin{aligned}
& \text { s.e. (between means of } \\
& \text { methods } A \text { and } B)=\left[\frac{s_{A}^{2}}{n_{A}}+\frac{s_{B}^{2}}{n_{B}}\right]^{1 / 2}
\end{aligned}
$$

Because the results of Test 7 indicate that differences among variances for the three casing methods are not significant, a pooled variance is used in this computation instead of variance values corresponding to individual methods. As shown in Table 3 , the difference between $\overline{\mathrm{I}}$ (drilled) and $\bar{I}$ (driven) is not significant and should be considered negligible. But the differences between $\bar{I}$ (augered) and $\bar{I}$ (drilled) and between $\overline{\mathrm{I}}$ (augered) and $\overline{\mathrm{I}}$ (driven) are much greater than the corresponding standard errors and, consequently, should be considered significant (Table 3 ). This conclusion is also illustrated with the e.d.f.'s of Figure 6 (a) for the neutron logs. The curve for I (augered) is clearly set apart from the other two, but the difference between the I (drilled) and the I (driven) curves is not readily apparent. Thus, if the absolute value of $\overline{\mathrm{T}}$ is thought to be a quantitative indication of disturbance, the results displayed in Tables 2 and 3 show that, according to the neutron logs, augering clearly produces the most disturbance of the three methods, while the mudrotary drilling and the driving methods produce a lesser, approximately equivalent, degree of disturbance in the vicinity of the borehole.

The neutron $\log$, with its 10 -inch spacing between source and detector, incorporates a relatively large volume of investigation. The measurement penetrates deep into the formation and, as such, it is not especially sensitive to resolving small disturbances near the casing. To improve this resolution, a natural gamma tool, with less penetration capability and a correspondingly smaller volume of investigation, was run in all 15 wells at this study site. Tests for normality were again conducted on these additional data sets. Subsequently, statistical Tests 1 through 7 summarized in Table 1 were repeated using the digitized natural gamma logs. These tests yielded the same conclusions previously obtained from processing the neutron logs regarding spatial heterogeneity and relative disturbance. Various statistical parameters, as 


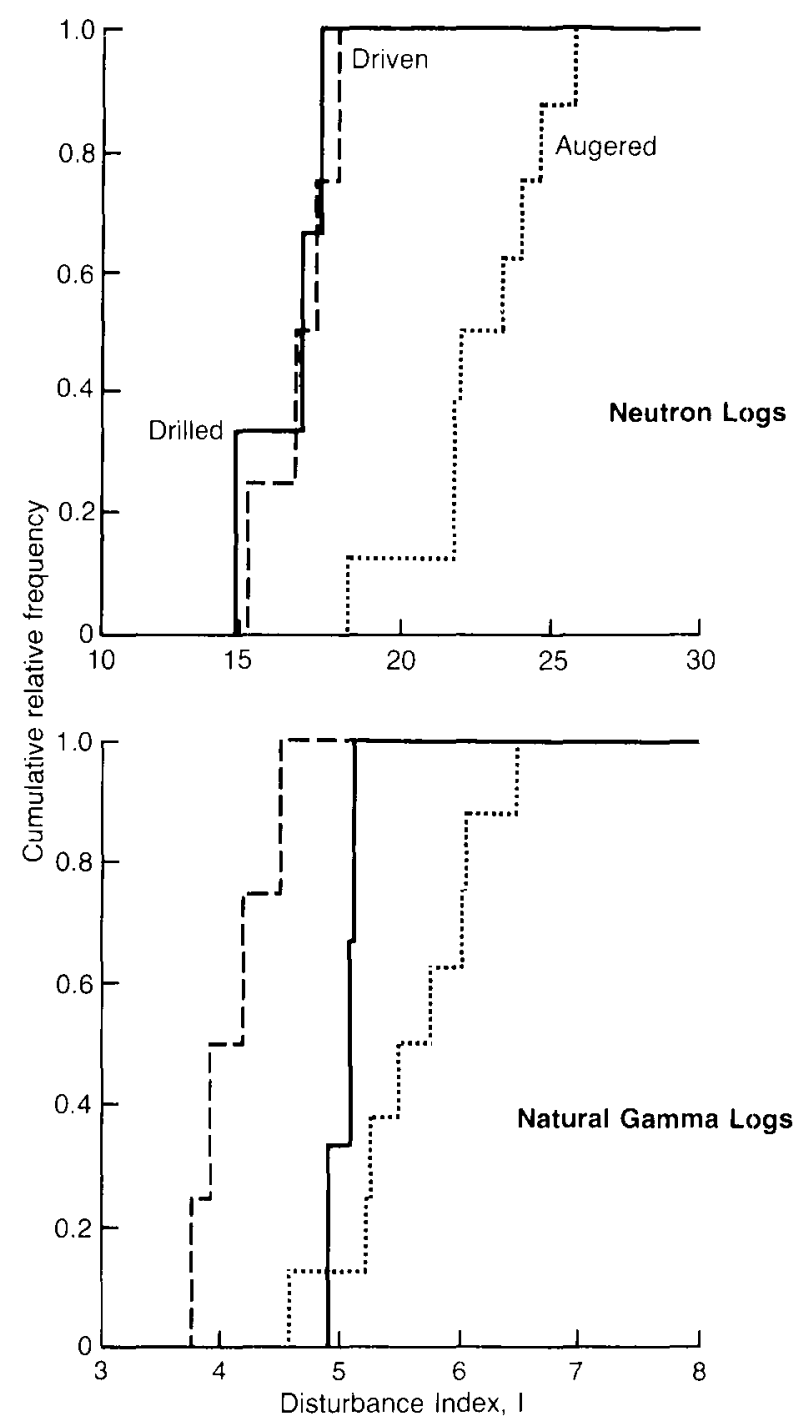

(a)

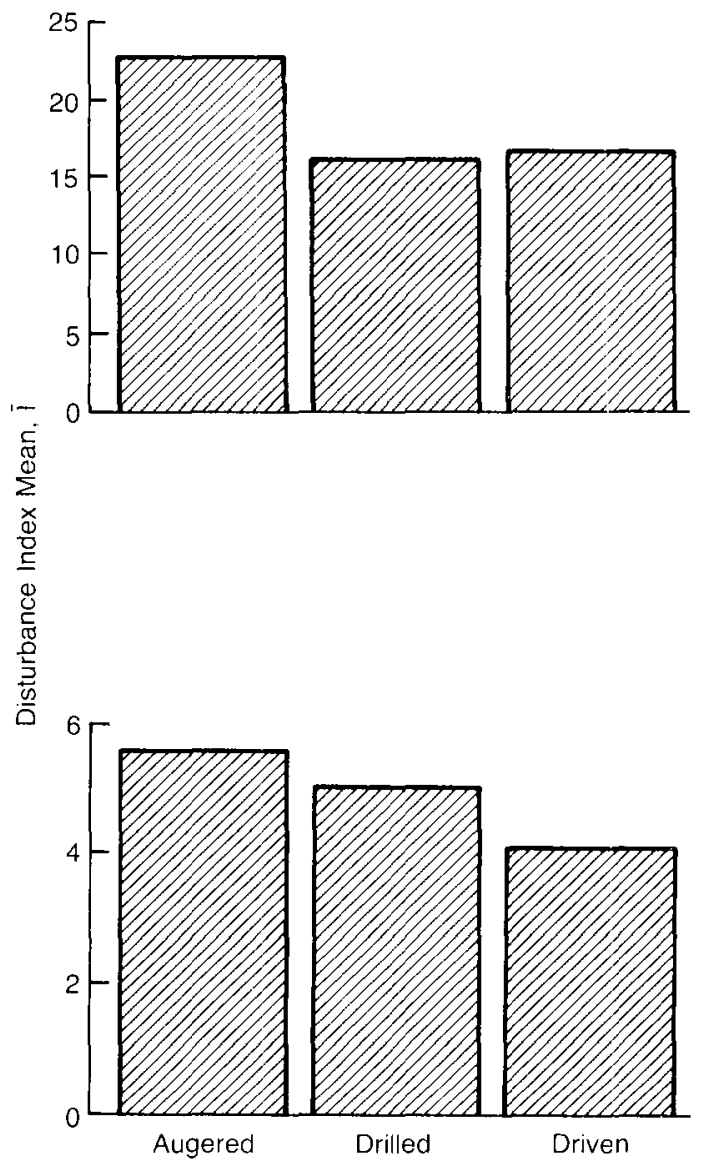

(b)

Fig. 6. (a) Empirical distribution functions of disturbance indices. (b) Bar graphs illustrating mean values of disturbance index. Both figures display data derived from neutron and natural gamma logs as a function of casing-installation method.

Table 2. Disturbance Parameters Classified in Terms of Casing-Installation Method

\begin{tabular}{|c|c|c|c|c|c|}
\hline \multirow[b]{2}{*}{ Installation method } & \multirow{2}{*}{$\begin{array}{c}\text { Number of } \\
\text { wells }(n)^{*}\end{array}$} & \multicolumn{2}{|c|}{ Neutron logs } & \multicolumn{2}{|c|}{ Natural gamma logs } \\
\hline & & $\bar{I}$ & $s^{2}$ & $\bar{I}$ & $s^{2}$ \\
\hline Hollow-stem augered & 8 & 22.7 & 5.30 & 5.59 & 0.353 \\
\hline Mud-rotary drilled & 3 & 16.2 & 2.18 & 5.03 & 0.014 \\
\hline Hammer driven & 4 & 16.6 & 1.65 & 4.08 & 0.100 \\
\hline
\end{tabular}

* $\mathrm{n}$ is the number of data samples in one data set. In this case, $\mathrm{n}$ equals the number of wells.

Table 3. Standard Errors Between Values of $T$ with Respect to Casing-Installation Method

\begin{tabular}{|c|c|c|c|c|c|}
\hline \multicolumn{2}{|c|}{ Installation metbod } & \multicolumn{2}{|c|}{ Neutron logs } & \multicolumn{2}{|c|}{ Natural gamma logs } \\
\hline A & B & $\left|\bar{I}_{A}-\bar{I}_{B}\right|$ & s.e. & $\left|\bar{I}_{A}-\bar{I}_{B}\right|$ & s.e. \\
\hline Augered & Drilled & 6.48 & \pm 1.33 & 0.56 & \pm 0.23 \\
\hline Drilled & Driven & 0.45 & \pm 1.50 & 0.95 & \pm 0.37 \\
\hline Driven & Augered & 6.03 & \pm 1.20 & 1.51 & \pm 0.29 \\
\hline
\end{tabular}


determined from the natural gamma logs and the neutron logs, are compared in Tables 2 and 3.

The natural gamma log, with its shallower penetration and higher resolution, produces a more distinct sequence of disturbance index values classified according to installation method. As listed in Table 3 and illustrated in the empirical distribution functions of Figure 6(a), the disturbances produced by the drilled and the driven techniques are now significantly different. Whereas the neutron-based analyses concluded that disturbances from mud-rotary drilling and from driving were approximately the same, the natural gamma-based analyses differentiate between these two methods and show that driving produces the least amount of disturbance. Both analyses (neutron and natural gamma) identify augering as the installation method that produces the largest disturbance.

\section{DISCUSSION}

Nuclear logs can be used effectively as stratigraphic indicators and, as such, can be an important facet of any hydrogeologic investigation which attempts to characterize aquifer properties. Formation disturbance in very loose, unconsolidated deposits produced during borehole construction and casing installation can seriously hinder the diagnostic capabilities of geophysical logs. Variable or inconsistent formation disturbance produced by different casing-installation methods within the same study area compounds this problem.

An "analysis of variance" investigation was designed to identify, quantify, and compare formation disturbances produced by three different casing-installation methods in unconsolidated sediments. A systematic and structured approach was designed to consider the effects of the numerous ancillary variables encountered, such as different types and sizes of casing, different logging tools, and natural variations among strata. Statistical processing of digitized nuclear logs produced evidence of spatial heterogeneity across the study site in a predominantly north-south direction. Because of this heterogeneity, variability in population variances and means was found to be a function of both location and casing-installation method. By introducing the disturbance index I into the analysis, spatial dependency was eliminated. The magnitude of I also provided a quantitative estimate of formation disturbance from which to compare the disruptive effects of several casing-installation methods.

Statistical tests using neutron logs and associated values of I helped categorize the three casing methods according to relative disturbance; additional analyses using the higher-resolution natural gamma logs verified and refined the results. Augering clearly produced the greatest amount of disturbance in the vicinity of the borehole. The relatively large outside diameter of the auger (6 $\frac{5}{8}$ inches) tended to disrupt a large proportion of the sediments surrounding the well, and a relatively large inside diameter ( $3 \frac{1 / 4}{4}$ inches) prompted additional collapsing around the casing. The mixing effect resulting from the combination of these two factors suppressed the stratigraphic detail and "smeared" the nuclear logs. Keely and Boateng (1987) have recognized this condition when augering in fluvial and glacial sediments.

Both mud-rotary drilling and driving methods offered significant improvements over augering in terms of disturbance, with driving being the least disruptive method (Figure 6). Consequently, for fine-scale studies of aquifer properties conducted in unconsolidated formations like those found at this Cape Cod site, observation wells produced with driven casing likely will yield geophysical logs that are more accurately representative of the undisturbed formation. This conclusion, however, should be considered in a proper frame of reference, realizing that geophysical logs obtained from augered wells may have genuine diagnostic value when gross stratigraphic features, as opposed to fine structure, are of interest. It should also be noted that the installation of driven wells typically requires more time, effort, and money than the installation of either augered or mud-rotary wells. For example, at the Cape Cod site, three augered wells of ten were completed in the same amount of time as was required to produce only one driven well.

\section{ACKNOWLEDGMENTS}

The authors would like to thank B. Troutman and $\mathrm{K}$. Hess, whose deliberate reviews improved this manuscript considerably. Additional discussions with F. Paillet and D. Helsel were also helpful.

\section{REFERENCES}

Anderson, M. P. 1979. Using models to simulate the movement of contaminants through groundwater flow systems. CRC Critical Reviews in Environmental Control. v. 9, pp. 97-156.

Conover, W. J. 1980. Practical Nonparametric Statistics. 2nd ed. Wiley, New York. 493 pp.

Gelhar, L. W. and C. L. Axness. 1983. Three-dimensional stochastic analysis of macrodispersion in aquifers. Water Resources Research. v. 19, no. 6, pp. 161-180. 
Hearst, J. R. and P. H. Nelson. 1985. Well Logging for Physical Properties. McGraw-Hill, New York. 571 pp.

Keely, J. F. and K. Boateng. 1987. Monitoring well installation, purging, and sampling techniques-Part 1 : Conceptualizations. Ground Water. v. 25, no. 3, pp. 300-313.

Keys, W. S. and L. M. MacCary. 1971. Application of borehole geophysics to water-resources investigations. Techniques of Water-Resources Investigations of the U.S. Geological Survey. book 2, chapt. E1, $126 \mathrm{pp}$.

LeBlanc, D. R. 1984a. Sewage plume in a sand and gravel aquifer, Cape Cod, Massachusetts. U.S. Geological Survey Water-Supply Paper 2218. 28 pp.

LeBlanc, D. R., ed. 1984b. Movement and fate of solutes in a plume of sewage-contaminated ground water, Cape Cod, Massachusetts. U.S. Geological Survey Toxic Waste Technical Meeting, Tucson, AZ, March 20-24, 1984. U.S. Geological Survey Open-File Report 84-475. $180 \mathrm{pp}$.

Le Blanc, D. R. $1984 \mathrm{c}$. Digital modeling of solute transport in a plume of sewage-contaminated ground water. In LeBlanc, D. R. 1984b (see above), chapt. B, pp. 11-45.

LeBlanc, D. R., S. P. Garabedian, R. D. Quadri, R. H. Morin, W. E. Teasdale, and F. L. Paillet. 1987. Hydrogeologic controls on solute transport in a plume of sewagecontaminated ground water, Cape Cod, Massachusetts. U.S. Geological Survey Toxic Waste Technical Meeting, Hyannis, MA, October 21-25, 1985. U.S. Geological Survey Open-File Report 86-481.

Lilliefors, H. W. 1967. On the Kolmogorov-Smirnov test for normality with mean and variance unknown. Journal of the American Statistical Association. v. 62, pp. 399-402.

Mackay, D. M., D. L. Freyberg, P. V. Roberts, and J. A. Cherry. 1986. A natural gradient experiment on solute transport in a sand aquifer. I. Approach and overview of plume movement. Water Resources Research, v. 22, no. 13, pp. 2017-2029.

Mather, K. F., R. P. Goldthwaite, and L. R. Thiesmeyer. 1942. Pleistocene geology of western Cape Cod, Massachusetts. Geological Society of America Bulletin. v. 53, pp. 1127-1174.

Molz, I. J., O. Güven, J. G. Melville, R. D. Crocker, and K. T. Matteson. 1986. Performance, analysis, and simulation of a two-well tracer test at the Mobile site. Water Resources Research. v. 22, no. 7, pp. 1031-1037.

Oldale, R. N. 1981. Pleistocene stratigraphy of Nantucket, Martha's Vineyard, the Elizabeth Islands, and Cape
Cod, Massachusetts. In Larson, G. J. and Stone, B. D., eds., Late Wisconsinan glaciation of New England. Dubuque, Iowa, Kendall/Hunt. pp. 1-34.

Shuter, E. and W. E. Teasdale. in press. Application of drilling, coring, and sampling techniques to test holes and wells. Techniques of Water-Resources Investigations of the U.S. Geological Survey. book 2, chapt. F1.

Snedecor, G. W. and W. G. Cochran. 1967. Statistical Methods. Iowa State University Press, Ames. 593 pp.

Sudicky, E. A., J. A. Cherry, and E. O. Frind. 1983. Migration of contaminants in groundwater at a landfill. A case study, 4. A natural gradient dispersion test. Journal of Hydrology. v. 63, pp. 81-108.

Sudicky, E. A. 1986. A natural gradient experiment on solute transport in a sand aquifer. Spatial variability of hydraulic conductivity and its role in the dispersion process. Water Resources Research. v. 22, no. 13 , pp. 2069-2082.

Roger H. Morin is a Geopbysicist with the Borebole Geopbysics Research Project, Water Resources Division, Denver, Colorado. He obtained B.S. and M.S. degrees in Mechanical Engineering from the University of Maine and a Pb.D. in Ocean Engineering from the University of Rbode Island, where be studied marine soil mechanics. He spent two years as a post-doctoral research scientist at the Massacbusetts Institute of Tecbnology before joining the U.S. Geological Survey in 1984. His research interests include the physical properties of soil and rock, and their influence upon geologic processes.

Denis R. LeBlanc is a Hydrologist with the U.S. Geological Survey in Boston, Massacbusetts, where be bas conducted several ground-water studies in New England. He received bis B.S. in Hydrology from the University of New Hampshire in 1975 and is presently conducting research in solute transport in ground water at the U.S. Geological Survey Toxic-Waste Research Site at Otis Air Force Base on Cape Cod, Massachusetts.

Warren E. Teasdale is Project Cbief, Research Drilling, Sampling, and Testing Techniques Project, Water Resources Division, Denver, Colorado. He received a B.A. degree in Geology from Hofstra University and bas been working for the U.S. Geological Survey since 1958. He bas worked on numerous research drilling projects througbout the world and bas recently served as a U.S.G.S. drilling consultant for the Ceological Survey of Bangladesh. 